\title{
MANAGEMENT AND RESEARCH WORKERS
}

$I^{N}$ $\mathrm{N}$ both industry and Government, a costly and dangerous trend is emerging - a trend towards a kind of management system the pattern of operation of which is incompatible with that required for highly oreative performance by scientific and engineering staff. It is a trend toward tighter budgetary controls and tighter organization of the work. It is brought about by the impact of greater competition and, even more, by faulty information concerning the relative effectiveness of various approaches to the reduction of cost and improved performance.

Prof. Rensis Likert suggests in the March issue of International Science and Technology that this is a dangerous trend because tighter controls, while appearing to provide desired results over a short-run period, may damage an organization over a longer span of time. As a counter-measure, he proposes a management system which enables scientists and engineers to function at their most creative level. This is a system which has evolved from an extensive programme of research by the Institute of Social Research of the University of Michigan. From the studies a number of observations concerning the performance of technical people has emerged.

When communications within the organization is frequent, scientists and engineers are likely to perform better. For example, patent applications by technical personnel are higher in such organizations, and employee evaluations of one another are also higher. Frequent communications with colleagues who think differently from one another also improve an organization's performance. Scientists who do communicate with one another, but who are not conscious of a need for competent colleagues-who maintain an independent frame of mind-tend to be better performers than those who are more dependent.

Scientists and engineers who see their administrative chief often perform better than those who do not. Their performance is better still when they can also set their own technical goals, or at least have some influence on their chief in setting those goals. Best performance is observed when the scientist has high self-determination combined with free access to someone in authority. The potentialities of younger subordinates are best developed by the supervisor who can maintain the difficult synthesis of close interest in the young man's work without domination of it. If the technical man's personal motivation is low and, if he is not deeply involved in his work. it is not advisable to allow more than moderate selfdetermination in his work. If his motivation is high, then full self-determination leads to best results.

These observations point to the important general conclusion that scientists and engineers are likely to be most creative when their supervision is such that they feel substantial freedom in their work-in selecting their problems and goals, in deciding on the approach to achievement, and in interpreting their data - and when they have frequent interaction with their superiors. These findings are valid for the administration of basic research, developmental research, and engineering. Such conclusions are often greeted with scepticism. To some it seems that the conclusions are obvious, needing no research to prove its validity. Many research directors argue that "my people do feel substantial freedom". Prof. Likert counters with examples to show that the true feelings of a manager's subordinates are probably quite different from what he believes them to be.

The other kind of scepticism involves a more traditional bias: if you allow too much freedom people will take advantage and the organization will suffer. Here studies have proved the reverse of this, but they have also shown that it takes time to institute such a programme. During a short period of, say, one year, the kind of programme proposed is likely to prove less productive than one that is oriented round tighter controls.

T. H. HAwKINS

\section{EDUCATION RESEARCH IN BRITAIN}

$I^{\mathrm{N}}$ $\mathrm{N}$ reply to a question in the House of Commons on April 19, the Minister of Education, Sir David Eccles, said that he had offered $£ 5,000$ a year for three years to the Educational Foundation for Visual Aids towards the running costs of its new experimental development unit; $£ 16,000$ over four years to the National Foundation for Educational Research for research into the relative merits of block release and day release; about $£ 12,000$ over three years to the University of Sheffield for research into the logical programming of mathematics syllabuses; and about $£ 9,500$ over four years to the University of Manchester for a sociological study in grammar schools. He expected that actual grants in 1962-63 for these projects would total about $£ 12,000$, and he was considering other applications.

Later, on April 19, in a debate on educational research opened by Mr. J. Boyden, the adequacy of the $£ 20,000$ which the Minister was making available for educational research was challenged. Starting with the comment in the Crowther Report that in a consistent programme of educational development almost the first step should be to review the provision for statistics and research, Mr. Boyden strongly urged more generous support for the educational research foundations. He also quoted Sir Howard Florey's appeal to the Parliamentary and Scientific Committee for greater support for university research. The universities needed more accommodation, more qualified and technical assistance and more adequate funds for research. In particular, evidence submitted to the Robbins Committee from the British Association for the Advancement of Science had been concerned with the relative lack of research facilities in sociology, social psychology and social anthropology. The lack of consistent policy in developing the social sciences within the university framework had very greatly added to the difficulties of building up a body of knowledge and methodology suitable for the study of the rapidly changing social conditions in Britain 
and elsewhere. It was still insufficiently realized that social fact-finding, by means of intensive and extensive field and documentary research, was both essential and very expensive. Finally, besides urging that every major educational undertaking should be so far as possible based on the results of research, Mr. Boyden suggested several questions in which research could provide a guide to policy; he also stressed the need for stable careers in educational research, and thought that a Council for Educational Research was desirable.

Mr. P. Goodhart thought that besides research into the problems of learning there was even greater need for research into the technological problems of British outlook. Mr. S. Irving suggested that one reason for the neglect of educational research was the tendeney to regard education as an art and not a science. Supporting the idea of a separate Council for Educational Research, he thought more coordination was needed, but that the main effort in research should not come under the establishment responsible for the administration of our educational system. He thought Britain could profitably spend $£ 25,000$ a year on such research, and in this view he was supported by Mr. A. Albu, who, however, thought that educational research should be part of a wider field-that of a social science or human sciences research council, rather than a separate educational research council. Mr. F. Willey, supporting the idea of an educational research council, thought that such a council should be responsible to the Lord President of the Council, and thought there should also be a close relationship with the Ministry of Education.

In replying to the debate, which he welcomed, Sir David Eccles agreed that the tendency to regard education as an art instead of a science might be one reason for the neglect of educational research, although more such research was proceeding than was generally known. Referring to the administrative changes which were in progress to expand research and intelligence in the Ministry, drawing largely on the Inspectorate for the staff of the new Curriculum Study Group, Sir David said besides this Group there was a new Research and Intelligence Branch and a much stronger Statistics Branch. For the moment, the main task of the Curriculum Study Group would be to identify gaps in our knowledge which might be filled by research, and the Research and Intelligence Branch would then see which of these gaps could be filled and by whom. Two kinds of project were visualized. The first of these would be organized from outside the Ministry, and here Sir David hoped to gain the assistance of a committee of experienced advisers, while the second would be organized within the Department to assist the Minister in policy decisions. At present the Curriculum Study Group was engaged on a study of examinations below the level of the General Certificate of Education arising out of the Beloe Report.

A new consortium of manufacturers and local authorities under the ægis of the London County Council, called the Science Equipment Consortium, was doing for science equipment what had been done for some building materials by the Architects and Buildings Branch. Besides the field of science teaching being taken up in the Nuffield Foundation project (see Nature, 194, 238; 1962) there was the whole field of visual aids. In conclusion, Sir David agreed as to the importance of stable careers for research workers, expressing also the opinion that some interchange between teaching, administration and research would be useful.

\section{THE WOOL INDUSTRIES RESEARCH ASSOCIATION}

THE report of the director of research*, Dr. A. B. D. Cassie, for 1961 , presented at the fortythird annual general meeting of the Wool Industries Research Association on April 11, refers to continued investigations into the causes of seasonal variation in wool production, including an intensive study of the causes of winter thinning or break in the staple, and of the incidence of shedding of fibres. Much work has been done on the identification and quantitative dotermination of different kinds of fibres in blends and an automatic amino-acid analyser based on the estimation of amino-acids as their copper complexes has been constructed. Extensive studies on the fractionation of $\alpha$-keratose and $\gamma$-keratose have shown them to be heterogeneous mixtures of similar peptides which are very susceptible to hydrolysis in alkaline media, and $\alpha$-keratose and $\gamma$-keratose are now believed to be sub-units of a protein structure of very high molecular weight. The - SS - and - SH contents of wool have been determined by polarographic methods which measure the uptake of various mercurials by virgin and reduced wool. Evidence has been obtained that the differences in the reactivity of the cystine fractions from wool keratin cannot be attributed to differences in accessibility of the cystine, to whether cystine forms intra- or inter-chain linkages, or to whether cystine is located in the fibrillar structure of the fibre

* Wool Industrles Research Association. Publication No. 218: Report of the Director of Research for 1961. Pp. 41. (Leeds: Wool Industries Research Association, 1062.) or the matrix surrounding the fibrils. Difficulties in measuring accurately diffusion of dyes in keratin have been largely overcome by using thin uniform sections of horn keratin cut by microtome to a thickness of about $7 \mu$.

Dr. Cassie also refers to further developments with the tension regulator developed for fitting to the Noble comb for controlling feed; to a continuing examination of the fundamental causes of fly waste; to further work on the effect of acid dyeing on the properties of carpet yarns and carpets. A survey of woollen and finishing operations following the tinter was commenced and attention directed to scouring in package form of worsted yarn containing a castor/ sperm type combing oil.

In his chairman's address at the annual general meeting, Mr. F. W. Hirst referred to the growth of co-operation and instanced the satisfactory shrinkresistance of knitted garments to-day resulting from the joint efforts of the Hosiery Research Association and the use of a Woollen Industries Research Association shrink-resist process. A Committee of Chairman and Directors of the Textile Research Association had considered ways of promoting closer working of Associations. Healthy co-operation between the industry and the International Wool Secretariat was noticeable, while another example of co-operation was to be seen in the resolution of problems of industrial relations by discussion between management and the Unions. 